\title{
World War I commemoration and student historical consciousness: A study of high-school students' views
}

\author{
Melanie Innes* and Heather Sharp - University of Newcastle, Australia
}

\begin{abstract}
Commemoration of World War I (WWI), and specifically the Gallipoli campaign, holds a significant place in the Australian public imagination. This is currently heightened with the WWI centenary commemorations (2014-18) occurring on a local, national and international scale. In the current political climate, there has been a resurgence of nationalism amid fear of terrorist attacks and uncertain political futures. Traditionally, history education has been considered, by some, a tool for the promotion of national identity, despite history education literature and many curriculum documents increasingly focused on fostering historical consciousness in students. The Gallipoli campaign, and subsequent Anzac mythology, has maintained a strong focus in Australia as a means of promotion, and often celebration, of Australian culture in public history, including personal and familial connections via ancestral participation in WWI. This article explores the types of historical education conducted in three high schools. As part of a regular history lesson, students were provided with five sources and a series of questions to answer about the Gallipoli campaign as a historical and commemorative event. Students' responses are analysed in this paper using Jörn Rüsen's typology of historical consciousness (Rüsen, 2004) to gain an understanding of how students think about the commemoration of the Gallipoli campaign. Specifically, this paper is interested in students' navigation of collective memory and nationalistic narratives evident in the public sphere and popular culture, and how these inform a sense of historical consciousness.
\end{abstract}

Keywords: history education; World War l; historical consciousness; secondary school; Australia; collective memory; national identity

\section{Introduction}

In the lead-up to and during the centenary commemorations of World War I (WWI), Australian commemorative events continue to occur on a national and international scale. The Gallipoli campaign, at least in the beginning years of the commemorations, featured prominently in public remembrance events and associated activities. Since 2015, commemorations have moved away from such a strong focus on Gallipoli, and now, especially encouraged by other funding initiatives, there is an increased focus on the history and commemoration of Australia's participation on the Western Front in Belgium and France. Australia's frequently nationalistic focus on its participation in WWI comes at a time of upheaval in world current events. Over the past two decades, despite globalization continuing and expanding, with concepts such as global village being touted, there has been a rise in nationalist agendas. National identity as a 
concept is complex, and potentially covers a wide range of political and philosophical perspectives. The complexity of the issue is raised by Whitty and Power (2002), Billig (1995), Wodak et al. (1999) and Giroux (1998). In asserting that issues of national identity and nationalism are still relevant in a world that is increasingly transnational and globalized (an issue also raised by Curthoys, 2002, 2003), Giroux addressed this issue as far back as 1998:

What I am resisting is the claim that nationalism can be associated only with ethnic conflict, that nationalism is witnessing its death knell, or that the relationship between nationalism and national identity can be framed only within a transnational discourse ... as important as the discourse of globalization might be, it cannot be used to overlook how national identity reasserts itself within new discourses and sites of learning. (Giroux, 1998: 179)

Billig (1995: 8) concurs with this, and his statement on the symbols of nationalism is particularly pertinent to this article:

There is a growing body of opinion that nation-states are declining. Nationalism, or so it is said, is no longer a major force: globalization is the order of the day. But a reminder is necessary. Nationhood is still being reproduced: it can still call for ultimate sacrifices; and, daily, its symbols and assumptions are flagged.

Building on the work of, among others, Ireland (2000), Giroux (1998), Wodak et al. (1999) and Billig (1995), nationalism and national identity are seen as part of a broader 'cultural identity' and debates in schooling contexts are concerned with 'the nature of national culture and civilization' (Husbands, 1996: 130). Giroux (1998: 179-80), in writing of the importance of identifying and acknowledging nationalism, states there is a 'need to acknowledge the existence of the nation-state and nationalism as primary forces in shaping collective identities'.

Focusing on the current political climate, with attacks on Western interests, and media coverage of these, and the resurgence of the political right and regressive politics - as seen in the Brexit vote taken by UK citizens to remove their country from the European Union, and the election of US Republican President Donald Trump, both in 2016 - the focus on nationalism and national interests at the expense of global partnerships (economic, social, cultural and political) remains. In 2017, this has been particularly heightened with the removal of monuments to controversial aspects of a nation's history, starting with the statue of General Lee (a well-known Confederate commander in the American Civil War) in Charlottesville, a city in the southern US state of Virginia. Monuments have long been a site of collective public gathering for Australians both at home and abroad when commemorating and remembering WWI. The monuments serve as a constant reminder about Australia's participation in WWI, and exist in far greater number than memorials for any other historical event, whether related to peacetime or conflict. The significance of WWI commemorations also attracts buy-in from: schools, through curriculum and ceremonies; religious (usually Christianbased) memorial services in formal settings (for example, churches) and in the public sphere (for example, through local parks); businesses, largely through advertising at key times of the year, usually Anzac Day and sometimes also Remembrance Day; and charities that focus on supporting returned servicemen and servicewomen. Through these actions, Gallipoli and, more broadly, WWI commemorations can be seen as a tool for celebration and promotion of a prescribed Australian culture in the public sphere. 


\section{History teaching in Australia}

Political interest in school history in Australia, particularly from those on the political right, has frequently been concerned with the task of helping to shape a national identity, or build national cohesion (see, for example, Donnelly and Wiltshire, 2014). However, Martin (2016: 6) argues:

Politicisation of school history engenders further tensions where there are significant disconnects between public and professional conceptions of history education. In the public discourse, history is associated with concepts of 'narrative, 'facts' and 'national life,' and this understanding is at odds with professional discussions that tend to focus on the development of historical understanding.

History education in Australia has at times been a topic of heated political debate, as politicians and other key stakeholders, such as parents, express concern about the alleged lack of content knowledge students are taught. At the same time, students themselves often reject Australian history, as they perceive it as boring - as reported in History's Children (Clark, 2008). Clark found that in addition to the general consensus among Australian students that Australian history is boring, many students felt an uncritical connection to the Anzac (Australian and New Zealand Army Corps) narrative, an issue that concerned many historians, teachers, and even students (ibid.). Since Clark's study, the Australian Curriculum has been implemented, including a focus on critiquing the Anzac legend. Therefore, this research is able to investigate whether the new curriculum has any impact on students' understanding of, and critical engagement with, Australia's commemorative acts and their political purposes.

Holbrook (2016) presents a history of how the greater public significance of Anzac, and specifically remembrance of the Gallipoli campaign, has evolved over time. The release of the highly successful Peter Weir film Gallipoli in 1981, which depicted the experience of the ordinary soldier, is considered to have had a significant impact on popular public understandings of this campaign. In particular, Holbrook (2016: 20) notes that, 'Gallipoli portrays the birth of Australian nationhood as a response to British bullying and incompetence, rather than as a product of heroic fighting against the Turkish troops'. This was a markedly different perspective on the event compared with pre-1960s views, for example, when Australians were arguably more concerned with Australia's integrity and worth as a member of the British Commonwealth. In recent decades, there has been a resurgence in passionate national commemoration of Anzac Day, particularly leading up to the centenary in 2015 (Clark, 2017). So tied is Gallipoli to the Australian national psyche, that any apparent criticism of Anzac mythology is often publicly attributed to being un-Australian, or lacking in core Australian values (Clark, 2016; Damousi, 2010; Lake, 2010; Brown, 2014).

Another factor that could be responsible for a resurgence of the Anzac legend is targeted government funding surrounding Gallipoli and WWI commemoration, which receives bipartisan political support. Since 2010, 'the collective efforts of Labor and Coalition governments have now seen Australia allocate more than $\$ 471.8$ million of Commonwealth and state money to the commemoration of World War I - a figure greater than all other nations combined' (Holbrook, 2016: 22). This intense politicization of the centenary commemorations comes at a time of national and international instability, and may be viewed as a political tool to strengthen national cohesion. Lake (2010) argues that in schools one element contributing to the resurgence of the Anzac legend is the distribution of Department of Veterans' Affairs (DVA) school curriculum 
resources, and public institutions devoted to the commemoration of Australia's military history. Martin (2016) argues that there is a dichotomy in the Australian history education context, represented by a clash of theoretical paradigms regarding the purpose of history education. She conceptualizes these paradigms as being either heritage or disciplinary; the former is primarily concerned with the task of nation-building, while the disciplinary paradigm espouses and engages with 'interlinking and substantive and procedural knowledge relevant to current practice within the discipline' (Martin, 2016: 10).

Following the implementation of the Australian Curriculum: History, the New South Wales (NSW) syllabus locates the Gallipoli campaign within the Stage 5 (school years 9 and 10, typically 14- to 16-year-olds) depth study Australians at War: World Wars I and II (1914-1918, 1939-1945). The final content points required of this unit concentrate on 'Commemorations and the nature of the ANZAC legend', with students specifically required to: 'explain how and why Australians have commemorated the wars' and 'explain different perspectives on the ANZAC legend' (Board of Studies NSW, 2012: 76-7). Arguably, with the inclusion of the history of commemorations of the Anzac legend, this strand of enquiry has a potential pedagogical impact when thinking of history from a disciplinary perspective, encouraging critical thought and an understanding of the contestable nature of history (Holbrook, 2016).

\section{Theoretical framework}

\section{Historical consciousness}

Since the 1970s, history education literature has increasingly focused on the formation of historical consciousness and the ways in which students construct their own narratives in order to understand themselves as historical figures (Laville, 2004). More recently, studies of historical memory have found that much of the history informing individual memory is linked to collective memories gained through public history and social interactions (Clark, 2014; Létourneau, 2006). In this way, history education has the capacity to assist students with a sense of the temporal nature of history (Rüsen, 1989), serving a greater sense of identity as historical knowledge begins to play a part in their everyday thinking $($ Lee, 2004). Rüsen's $(1989,2004)$ disciplinary matrix describes the relationship between disciplinary historical knowledge and history in practical life, informing a sense of historical consciousness. Most recently, Seixas (2016) built on Rüsen's disciplinary matrix, arguing that the original context of Rüsen's creation of the disciplinary matrix was before memory studies as an academic field became more established. Therefore, Seixas's adaptation of the matrix is significant in the context of the analysis of students' understandings of Gallipoli commemorations, due to the inclusion of memory practices in everyday life. For this adaptation of the matrix, see Seixas (2016).

\section{Analytical framework}

This project uses the analytical framework drawn from Jörn Rüsen's $(1989,2004)$ typology of historical consciousness. Further examinations by Lee (2004) and Seixas (2005) have also been considered. The typology is composed of four types or forms of historical consciousness: traditional, exemplary, critical and genetic. Lee (2004) emphasizes that these forms of historical consciousness may coexist, or shift, depending on the individual's encounter with the past. Here is a brief overview of each of the four forms of historical consciousness: 
- Traditional historical consciousness considers historical knowledge as fixed and unquestioned, seeing values as valid and unchanging over time.

- Exemplary historical consciousness provides a conception of time as everchanging, while human conduct remains valid. It is in this way that exemplary historical consciousness considers history as containing lessons to guide us in the future.

- Critical historical consciousness challenges the previous types, being distinct from these forms in producing critical histories as a means of critiquing takenfor-granted moral values.

- Genetic historical consciousness conceives of time and values systems as everchanging. This form of historical consciousness stands beyond the previous three, as it also acknowledges that the historical interpretation of the individual is relational to their temporal perspective (Lee, 2004; Rüsen, 1989, 2004).

Seixas (2005), while aiming to develop a model linking historical consciousness to school contexts, drew on Rüsen's typology of the four types of historical consciousness as a means of analysing student historical consciousness. However, in the development of this framework, Seixas (2005: 142) links this approach to his elaboration of 'seven issues encountered by historical thinkers'. These issues of historical thinking are very closely aligned with the historical thinking concepts adopted in the current history syllabus used in NSW schools (Board of Studies NSW, 2012). Indeed, Seixas's later research would form key texts outlining historical thinking for history education (for example, Seixas and Morton, 2013). (Seixas is also the current director of the Historical Thinking Project at the University of British Columbia.)

\section{Methodology}

In 2015, a research project was conducted in Australian high schools, coinciding with the early phase of the roll-out of commemorative events for the official centenary of WWI. At that time, the focus of commemoration was on the Gallipoli campaign. High schools across the state of New South Wales were invited to participate in the research. History teachers self-selected to participate in the project, and students from their classes were invited to participate. Those students who declined were given an alternative activity to complete. The aim of the research was to gain an insight into what high-school students thought about Gallipoli commemorations. Participants were provided with a five-page work booklet designed specifically for the project, in which they were invited to answer a few brief biographical questions, and to answer, within 45 minutes, three questions about Gallipoli. In total, 82 students participated in the research across three high schools - an all-boys high school, an all-girls high school and a co-educational (mixed-sex) high school. Given the complexity and contradictions surrounding the Gallipoli campaign in Australian public history, this research was particularly interested in students' navigation of collective memory and nationalistic narratives evident in the public sphere and popular culture, and how these inform a sense of historical consciousness surrounding the Gallipoli campaign. This paper analyses what forms of historical consciousness are evident in student responses.

From the 82 student participants, 76 students displayed evidence of historical consciousness within their responses. The participants were coded with their school year level as the first numeral, followed by letters as a school pseudonym code, with final numerals indicating the order in which participants from each school were coded. For example, 8WC21 indicates that the student is in year 8, from ' $W C^{\prime}$ school, and 
was the 21st of the respondents analysed. The students were asked to respond to the following questions:

1. Is Gallipoli a significant event for us to remember today? Why or why not?

2. How should Gallipoli be remembered today?

3. Describe any perspectives/viewpoints about Gallipoli that you feel are missing from Sources A to E. (The sources were: a historical photograph of wounded troops on the beach at Anzac Cove; a promotional poster for the television series Anzac Girls (2014); a diary entry written by a soldier at Gallipoli; and two photographs, one of commemorative Anzac Day services at a cenotaph in Australia, and one of the pilgrimage of young Australians and New Zealanders to Gallipoli, Turkey.)

Significantly, 42 (56 per cent of the students displaying some form of historical consciousness) of the student responses adhered to traditional forms of historical consciousness, suggesting the strong pedagogical impact of public and collective forms of commemoration surrounding Anzac Day and Gallipoli remembrance. The following section discusses student responses found to display each form of historical consciousness, as well as how these findings contribute to an understanding of how to approach issues of national significance in history teaching.

\section{Findings}

Table 1 indicates the number of participants whose responses evidenced each form of historical consciousness.

Table 1: Number of participants demonstrating each form of historical consciousness

\begin{tabular}{ccccc}
\hline School year: & Traditional & Exemplary & Critical & Genetic \\
\hline $\mathbf{8}$ & 13 & 0 & 2 & 0 \\
9 & 8 & 4 & 5 & 0 \\
10 & 5 & 3 & 1 & 0 \\
11 & 1 & 1 & 0 & 0 \\
12 & 15 & 5 & 8 & 4 \\
TOTALS: & 42 & 13 & 16 & 4 \\
\hline
\end{tabular}

\section{Traditional historical consciousness}

A very strong theme of sacrifice was present within responses displaying traditional forms of historical consciousness. Notably, many of the students in Year 8 (one year before learning about Gallipoli in the Year 9 unit) who displayed traditional forms of historical consciousness adhered to a narrative of sacrifice, connected to a sense of undefined present-day freedom. As an example, 8WC21 responds in the affirmative to Question 1: 'Gallipoli was a massive war where thousands of people gave their life to save their country and family from the enemy that is why we should never stop remembering them.' Additionally, 8WC11 displays a strong adherence to the traditional moral obligation of showing respect for the soldiers who sacrificed their lives for 'our' benefit, stating:

[...] people fought for our country and the brave people who fought day and night. People/soldiers died for us to be a better country and a safer 
one too. It would be disrespectful for us not to remember the dead and the survivors.

Similarly, while not an explicit reference to sacrifice, 8WC28 states: 'Gallipoli is a significant event for us today because without the people volunteering most of us wouldn't be here', suggesting that without the involvement of Australians at Gallipoli, Australian society and history would have been very different.

Senior student 12WC32 aligns to traditional values when discussing Gallipoli remembrance. Advocating for the continuation of the current means of commemoration, and directly using provided sources, he writes:

Gallipoli is a significant event for us to remember today as it is a direct link to our Australian past ... This conveys the significance of Gallipoli to Australians, particularly young people, which establishes that this event is significant to all generations of Australians. This significance stems from sacrifice of Australian men at Gallipoli where countless men were wounded and killed ... The ultimate sacrifice these men paid for our country is remembered and commemorated annually in Anzac day services and special events ...

Drawing on traditional narratives of bravery, 9WC4 responded to Question 2: 'We should remember it as an event where Australian soldiers showed true courage to fight for their country, even if the odds were against them.' In addition, he felt that the sources lacked representation of an undefined Anzac spirit, writing, 'None of the sources display the spirit that the soldiers showed while fighting in Gallipoli.'

Commemoration of Gallipoli in the public sphere can come in a variety of forms; as 10WC57 explains, he feels that Gallipoli should be commemorated through adherence to traditional values of 'solemness and respect'. His response to Question 2 specifically addresses this point:

I personally believe that Gallipoli should be remembered with a little bit more solemness and respect. The recent Woolworth's Fresh in our Mind campaign is one such instance, where the campaign's name and cause was not treated as seriously as it should have been. This is not an isolated incident as you see many companies/brands trying to take advantage of the battle to try and improve sales revenue. I find this incredibly disrespectful.

Furthermore people treat the battle with little respect as you see people having concerts (parties at Gallipoli to 'commemorate' the battle). However I don't see how it is very respectful the boys certainly didn't have a party. Even if you see Gallipoli as a celebrated victory - which it wasn't, it should still be treated with solemn respect through means such as the dawn services, masses, parades etc.

In his response, 10WC61 not only adheres to traditional narratives surrounding Gallipoli, but also includes descriptive details, arguably similar to those often seen in popular culture forms of commemoration:

Gallipoli is a significant event to remember because the pain and loyalty that the ANZACs shared is an experience that shaped the Australian culture. As the first wave of soldiers landed on Gallipoli soil, hundreds of men fell to flesh piercing spray of machine gun fire, blood wrenching barbed wire and life sapping disease. The pain these men suffered never 
stopped them from fighting a literal uphill battle to their last breath, this great sacrifice of human beings in the name of country should never be forgotten as it gave Australia/New Zealand an inspiration to aspire to. Moreover the un-defied loyalty that the soldiers had for each other, a loyalty that prevented no body be left, defined the type of person to aim to be.

In what is arguably the strongest example of adhering to traditional, nationalistic historical narratives, specifically the so-called Anzac spirit, 12WC34 argues for the continuation of traditional commemoration rituals, and interestingly uses the sources provided to justify his response, cleverly using these sources to justify his existing beliefs rather than to take a critical stance. He writes:

Gallipoli is an extremely significant event for Australians as it is the personification of the Australian Spirit. The Gallipoli campaign is the first campaign in which Australians fought under their own flag and fighting for their own country. This brought out the true Australian; the innovative, tough, and cheerful men who fight for the men next to them.... After the Gallipoli campaign, the Australian population grew a newfound nationalism and patriotism.

It may be argued that the proportion of students displaying traditional historical consciousness is evidence of the strong pedagogical impact of commemoration in the public sphere and in popular culture. In particular, students in Year 8, who have not yet studied Gallipoli in the school context, were largely represented in this sample (13 of the 22 Year 8 student respondents), arguably highlighting how interactions with Gallipoli remembrance in everyday life encourages adherence to nationalistic narratives.

\section{Exemplary historical consciousness}

Some historians have noted there has been a rise in narratives of victimhood relating to Australia's involvement in Gallipoli (Clark, 2017). This notion was evident in the majority of those responses that displayed exemplary forms of historical consciousness. Overall, 13 responses displayed exemplary historical consciousness. Students expressed that Australians should learn from the Gallipoli campaign, with a sense that such remembrance is a lesson or reminder to seek peace in the present. In her answer to Question 2, 9AGHS1 demonstrates exemplary forms of historical consciousness, stating:

The way that Gallipoli is remembered today is quite a glorified version of events. I do believe that the people involved showed great courage in the face of adversity but I think that as a whole the loss encountered in war far outbalances the bravery that we remember. Gallipoli should be seen as a way to remember the past and to acknowledge that we have grown since then, grown from the ideas that war is a noble notion and instead see it as something we no longer need.

This suggests that 9AGHS1 thinks we should acknowledge that 'we have grown since then', and look at wartime experience within the context of progress. Furthermore, 9AGHS1 mentions her hopes for a peaceful future, if Gallipoli is remembered in this way: 'That is the peace I hope to see in the future.' As Seixas (2005: 147) explains:

[...] increased knowledge helps, in the exemplary orientation, to promote the increased rationality of modern life. People understand that their lives 
are shaped - or might be shaped - not by irrational forces, but by human agents, and see their own power to control their own destiny.

A number of students displaying exemplary forms of historical consciousness felt that there is too much emphasis on remembering only the Gallipoli campaign, and that other campaigns should also be the focus of remembrance. As an example, 9AGHS4 states:

Gallipoli should be remembered with all of the other battles and wars on Remembrance Day. It should not be idolised or projected as the only war that Australia has ever been in and the others be thrown away. It should be classed as an equal war. Anzac Day celebrations should not just commemorate soldiers, navals and aircraftsmen but all the support staff like the nurses and the doctors.

This response corresponds with exemplary forms of historical consciousness, as she considers Gallipoli to be no more significant than 'other battles and wars', as well as placing significance on those involved in the Gallipoli campaign other than armed forces, suggesting a more progressive understanding of historical significance. As Seixas (2005: 147) argues, 'the largest events from history - those affecting the most people over the greatest length of time - are the most significant, because they teach us the most important things about what we need to know today'.

\section{Critical historical consciousness}

Many of the 16 students who demonstrated critical forms of historical consciousness expressed opposition to the mainstream focus of the heightened place of Gallipoli in Australian history. For example, 9AGHS9 demonstrates this idea as she expresses a view that there is too much focus on Gallipoli at the expense of other WWI battles, such as those on the Western Front. She is also concerned by the lack of representation of people other than Australians in the sources provided, specifically mentioning that 'the casualties at Gallipoli were not confined to the Anzac soldiers alone. Turkish people died and were wounded.' Here, she is demonstrating an understanding that WWI was indeed an international conflict, and should be remembered as such by Australians. Her response, in full, reads:

I think that Gallipoli is a significant event and that it should be remembered, but I think that there is far too much focus on it. I think that many Australians, especially younger children, are commemorating Gallipoli without any awareness of what actually happened, why it happened, and how the casualties at Gallipoli compared to casualties in other wars.... I also believe that there is too much focus put on the Australians who fought. While I understand that many people feel an emotional connection to others who happen to live within the borders of their own country - however arbitrary those borders are - I feel that this is causing many people's worldview and understanding of history to be biased. Each source provided has been centred around Australians, and yet the casualties at Gallipoli were not confined to the ANZAC soldiers alone. Turkish people died and were wounded, German people, Australians, Hungarians, Russians, British, French, and yet everything we are taught about Gallipoli and World War I is centred around Australians. 
There is evidence of critical forms of historical consciousness in answer to Question 1 when $12 \mathrm{MHS7}$ states: 'even if the morals of the battle weren't just we all must remember the young and the old that laid down their lives for their family and for their country.' His reference to unjust morals acknowledges that morals and values can be relative to time, and therefore subject to critique. In the same way, 10WC55 challenges traditional forms of remembrance, and states:

To remember these events we should recognize the people who were involved but I don't believe this should be the only focus. Australians tend to care more about things if they involve Australian people suggesting that Australians are more important. Kids should still learn about Gallipoli in school but, I think there are other things that should be taught too.

His response suggests a critical reflection on a general heightened sense of interest in events involving Australians, suggesting that he feels that there should be a reevaluation of what he perceives as the significance placed on Gallipoli in the school curriculum.

\section{Genetic historical consciousness}

Only four students displayed genetic forms of historical consciousness when considering Gallipoli remembrance. Significantly, all of these students were in Year 12 - their final year of schooling. This possibly reflects the transformative pedagogical impact of school history education, and the work teachers do to encourage students to view history through the lens of a historian. As an illustration, 12 WC52 presents a sophisticated consideration of the temporal nature of history and changes in commemoration over time. His answer to Question 1 reads:

In recent years, the remembrance of Gallipoli has become more significant than in the past, with re-established cultural events making Anzac Day a significant day in the nation's sporting and social calendar ... The significance of the event has spread widely in the past decades, mainly because of the historical theory that the events in the Dardanelles saw the birth of Australia as a nation and one with a separate identity to Great Britain.

This response reflects an understanding that there are differing perspectives surrounding remembrance and commemoration of the Gallipoli campaign. The discussion of notions of significance as 'spreading widely' over time, and changing 'historical theory' reflects genetic historical consciousness, as historical understanding is understood to be relative to time and place, as well as to evolving understandings and perspectives within the history discipline.

\section{Conclusion}

Overall, participant responses to the three questions indicate that they do agree that Gallipoli is a significant event to remember, regardless of which form of historical consciousness they displayed. In response to Question 2, participants reported varying perspectives on how it should be remembered, from nationally specific commemorative events to more globally oriented acts of remembrance that also include Turkey, the former enemy. Students are clear that perspectives other than those of Australian soldiers were missing from the sources provided, such as those of nurses and Indigenous Australians, as well as soldiers from other countries. 
Remembrance of the Gallipoli campaign in Australia is, and has been, an important bipartisan political tool for fostering a sense of national identity in a time of global political upheaval. In particular, the notion of the Anzac legend has been used in different ways over time as a symbol of Australian identity. However, this understanding of history is often at odds with disciplinary conceptions. The findings of this research are indicative of the complexity surrounding remembrance of the Gallipoli campaign in Australia, as well as reflective of the dichotomy described by Martin (2016), with clear connections to narratives associated with nation-building, as well as evidence of historical understanding. The political concerns with both how history is taught in Australian schools and the use of the Anzac legend as a symbol of Australian nationalism have had an impact on how this historical event is understood by students.

While the current Australian curriculum requires students to consider the commemoration of Gallipoli over time, implying an encouragement of critical thinking and an understanding of contestability, it is clear that many students still feel a deep emotional connection to Anzac. Of the sample reported in this research, over half of the students displayed traditional forms of historical consciousness, with representation from school years 8 to 12. These students cited their understanding of the significance of the Gallipoli campaign for the Australian nation, particularly as a sacrifice for the nation. Similarly, responses displaying exemplary forms of historical consciousness still held to the values associated with the Anzac legend, while feeling that there were lessons that could be learned from this experience to shape the future of the nation. The strength of this theme suggests that this nationalistic narrative is still being reproduced (Billig, 1995). The evidence that students are also resisting these narratives, particularly in their post-Year 9 schooling, also indicates the strength of the transformative aspects of the curriculum.

This research is potentially significant in increasing an understanding of the fostering of historical consciousness in schools. The strong emphasis on the Gallipoli campaign in national public commemoration, as well as representation in popular culture, allowed for an exploration of student historical consciousness surrounding this particular event, as most students, even those who have not yet studied the topic in schools, will have an understanding of Gallipoli through public history and national commemorative events. History education in Australia is a topic of political and public interest, creating a tension between theoretical understandings of the nature of history and the content taught. The use of Rüsen's (2004) typology as a means of analysing student historical consciousness, as well as consideration of Seixas's (2005) development of this framework linking with historical thinking concepts, enables the development of an understanding of student historical consciousness in this context. While teachers have a clear pedagogical impact, the large representation of students adhering to traditional narratives who had not yet studied this topic at school shows that historical consciousness and historical thinking concepts are often unable to be assessed through traditional preferred measures. The use of this framework may provide important insights into student historical consciousness informing pedagogical decisions.

\section{Notes on the contributors}

Melanie Innes is a PhD candidate and sessional academic at the University of Newcastle, Australia. She is an active member of the HERMES Research Group. Her research constitutes a curriculum enquiry, investigating digital and disciplinary literacies 
in New South Wales history education in the twenty-first century, as well as exploring student engagement with societal curriculum, and their navigation of online historical representation.

Heather Sharp, PhD, is a senior lecturer at the University of Newcastle, Australia. She is convenor of the History Network for Teachers and Researchers (HNTR), and a special issues editor of Historical Encounters. Her current research investigates the teaching of difficult and controversial pasts, the influence of public history in teaching, and historical representations in school curricula - particularly textbooks - and also examines the written and visual texts in picture books that deal with conflict.

\section{References}

Billig, M. (1995) Banal Nationalism. London: SAGE Publications.

Board of Studies NSW (2012) History K-10 Syllabus: Vol. 2: History, years 7-10. Sydney: Board of Studies NSW.

Brown, J. (2014) Anzac's Long Shadow: The cost of our national obsession. Collingwood, VIC: Redback.

Clark, A. (2008) History's Children: History wars in the classroom. Sydney: University of New South Wales Press.

Clark, A. (2014) 'Inheriting the past: Exploring historical consciousness across generations'. Historical Encounters: A Journal of Historical Consciousness, Historical Cultures, and History Education, 1 (1), 88-102.

Clark, A. (2016) Private Lives, Public History. Carlton, VIC: Melbourne University Press.

Clark, A. (2017) 'The place of Anzac in Australian historical consciousness'. Australian Historical Studies, 48 (1), 19-34.

Curthoys, A. (2002) 'Does Australian history have a future?'. Australian Historical Studies, 33 (118), 140-52.

Curthoys, A. (2003) 'Cultural history and the nation'. In Teo, H.-M. and White, R. (eds) Cultural History in Australia. Sydney: University of New South Wales Press, 22-37.

Damousi, J. (2010) 'Why do we get so emotional about Anzac?'. In Lake, M., Reynolds, H., McKenna, M. and Damousi, J. What's Wrong with Anzac? The militarisation of Australian history. Sydney: University of New South Wales Press, 94-109.

Donnelly, K. and Wiltshire, K. (2014) Review of the Australian Curriculum: Final report. Canberra: Australian Government Department of Education. Online. https://docs.education.gov.au/system/ files/doc/other/review_of_the_national_curriculum_final_report.pdf (accessed 26 June 2018).

Giroux, H.A. (1998) 'The politics of national identity and the pedagogy of multiculturalism in the USA'. In Bennett, D. (ed.) Multicultural States: Rethinking difference and identity. London: Routledge, 178-94.

Holbrook, C. (2016) 'Are we brainwashing our children? The place of Anzac in Australian history'. Agora, 51 (4), 16-22.

Husbands, C. (1996) What is History Teaching? Language, ideas and meaning in learning about the past. Buckingham: Open University Press.

Ireland, T. (2000) 'The archaeology of nation in Australia'. World Archaeological Bulletin, 11, 67-93.

Lake, M. (2010) 'Introduction: What have you done for your country?'. In Lake, M., Reynolds, H., McKenna, M. and Damousi, J. What's Wrong with Anzac? The militarisation of Australian history. Sydney: University of New South Wales Press, 1-23.

Laville, C. (2004) 'Historical consciousness and historical education: What to expect from the first for the second'. In Seixas, P. (ed.) Theorizing Historical Consciousness. Toronto: University of Toronto Press, 165-82.

Lee, P. (2004) '“Walking backwards into tomorrow": Historical consciousness and understanding history'. International Journal of Historical Learning, Teaching and Research, 4 (1).

Létourneau, J. (2006) 'Remembering our past: An examination of the historical memory of young Québécois'. In Sandwell, R.W. (ed.) To the Past: History education, public memory, and citizenship in Canada. Toronto: University of Toronto Press, 70-87.

Martin, B. (2016) 'Debating history in the Australian curriculum: A clash of paradigms?'. Agora, $51(1), 4-12$. 
Rüsen, J. (1989) 'The development of narrative competence in historical learning: An ontogenetic hypothesis concerning moral consciousness'. History and Memory, 1 (2), 35-59.

Rüsen, J. (2004) 'Historical consciousness: Narrative structure, moral function, and ontogenetic development'. In Seixas, P. (ed.) Theorizing Historical Consciousness. Toronto: University of Toronto Press, 63-85.

Seixas, P. (2005) 'Historical consciousness: The progress of knowledge in a postprogressive age'. In Straub, J. (ed.) Narration, Identity, and Historical Consciousness. New York: Berghahn Books, 141-59.

Seixas, P. (2016) 'A history/memory matrix for history education'. Public History Weekly, 4 (6). Online. https://public-history-weekly.degruyter.com/4-2016-6/a-historymemory-matrix-for-historyeducation/ (accessed 26 June 2018).

Seixas, P. and Morton, T. (2013) The Big Six Historical Thinking Concepts. Toronto: Nelson Education.

Whitty, G. and Power, S. (2002) 'The overt and hidden curricula of quasi-markets'. In Whitty, G. Making Sense of Education Policy: Studies in the sociology and politics of education. London: Paul Chapman, 94-106

Wodak, R., de Cillia, R., Reisigl, M. and Liebhart, K. (1999) The Discursive Construction of National Identity. Trans. Hirsch, A. and Mitten, R. Edinburgh: Edinburgh University Press. 